\title{
Arytmia i kobiety Sprawozdanie z pierwszego spotkania EPIC-Alliance w Polsce
}

\author{
Arhythmias and women. The first meeting of EPIC-Alliance in Poland
}

\author{
Barbara Małecka \\ Klinika Elektrokardiologii Instytutu Kardiologii Collegium Medicum Uniwersytetu Jagiellońskiego w Krakowie
}

Gościnne progi hotelu Lawendowe Termy w Uniejowie 12 i 13 marca br. były miejscem spotkania kobiet kardiologów zajmujących istotną pozycję w dziedzinie leczenia zaburzeń rytmu serca. Spotkanie zainicjowała firma BIOTRONIK, w ramach działającej od 2010 roku na forum światowym grupy EPIC-Alliance - Electrophysiologist International Community Alliance. Cytując przesłanie z agendy: „(...) ta forma zrzesza grono wiodących osób - kobiet kardiologów zajmujących się elektroterapią i elektrofizjologią. Jej celem jest tworzenie globalnej sieci wymiany doświadczeń i wiedzy. Współdziałanie ma zachęcić do podejmowania przez kobiety specjalizacji z elektroterapii i elektrofizjologii oraz ułatwiać rozwój karier w tej trudnej dziedzinie medycyny". Trudu realizacji pierwszej tego typu konferencji w Polsce wraz z ułożeniem programu naukowego i wyboru tematyki spotkania podjęy się Panie Profesor Katarzyna Mizia-Stec i Anna Maria Wnuk-Wojnar z Kliniki Kardiologii Śląskiego Uniwersytetu Medycznego w Katowicach Ochojcu. Logistyczne zabezpieczenie zapewniła firma Biotronik w ramach grantu edukacyjnego Akademii Elektroterapii.

Podczas pierwszej sesji przedstawiono problemy migotania przedsionków w ocenie Pań Kardiologów. Beata Wożakowska-Kapłon (Kielce) porównała skale służące ocenie ryzyka zakrzepowo-zatorowego, przedstawiając równocześnie własne doświadczenia w ich zastosowaniu w praktyce klinicznej. Poruszyła problem schorzeń nasilających ryzyko zakrzepowo-zatorowe, które nie zostały uwzględnione w tych skalach, jak chociażby przewlekła choroba nerek. Maria Trusz-Gluza (Katowice) w wykładzie o leczeniu inwazyjnym migotania przedsionków poruszyła między innymi problem kwalifikacji do ablacji/izolacji żył płucnych oraz okluzji uszka lewego przedsionka. W kontynuacji tego tematu Anna Maria Wnuk-Wojnar (Katowice) zaprezentowała film z zabiegu ablacji migotania przedsionków nakręcony w Klinice Kardiologii w Katowicach Ochojcu, opatrując go swoim autorskim komentarzem. Wobec trud- ności z uzyskaniem dostępu do zabiegów ablacji migotania przedsionków przez wszystkich chorych cierpiących na tę arytmię w Polsce i na świecie Iwona Cygankiewicz (Łódź) przedstawiła wykład „Kiedy nie kierujemy chorego do ablacji AF". Następnie Danuta Czarnecka (Kraków) ustosunkowała się do braku jednoznacznej interpretacji zaleceń na temat leczenia przeciwzakrzepowego i antyarytmicznego podczas zabiegu ablacji migotania przedsionków i po nim.

Kolejne dwie sesje na temat programowania urządzeń i nowości technologicznych zostały przeplecione przypomnieniem historii. Kalina Kawecka-Jaszcz (Kraków) przedstawiła rozwój krakowskiej elektrokardiologii jako spuścizny po Profesorach Leonie Tochowiczu i Władysławie Królu. Niestety, zabrakło w tej sesji udziału wieloletniej przewodniczącej Sekcji Rytmu Serca Polskiego Towarzystwa Kardiologicznego - Wiesławy Piwowarskiej i omówienia drugiego nurtu krakowskiej elektrokardiologii, płynącego szerokim i wartkim strumieniem na krakowskim Prądniku (nazwa własna od lokalnej rzeki), w szpitalu noszącym obecnie imię Jana Pawła II. To w tym właśnie szpitalu w 1978 roku utworzono pierwszą w Polsce Klinikę Elektrokardiologii Akademii Medycznej w Krakowie, prowadzoną od początku przez Profesora Ludwika Sędziwego. Obecnie, pod kierownictwem Jacka Lelakowskiego, Klinika podejmuje wszystkie zabiegi elektroterapii, łącznie z operacyjnym leczeniem powikłań, w tym przezżylnym usuwaniem elektrod endokawitarnych, z zachowaniem najwyższych standardów. Jeden z patronów spotkania i jednocześnie męski „rodzynek” konferencji - Jarosław Kaźmierczak (Konsultant Krajowy w dziedzinie kardiologii) przedstawił historię „młodego" ośrodka elektroterapii w Szczecinie. W sesji nie mogło zabraknąć Grażyny Świąteckiej (Gdańsk) wraz ze wspomnieniem pierwszej - historycznej - implantacji stymulatora w Gdańsku. Pierwsze w Polsce zabiegi implantacji kardiowertera-defibrylatora i ablacji łącza przedsionkowo-komorowego miały miejsce w Katowicach Ochojcu. Ich historię oraz zasługi Profesora Leszka Gieca omówiły Maria

Adres do korespondencji: prof. dr hab. n. med. Barbara Małecka, Klinika Elektrokardiologii, Instytut Kardiologii, Collegium Medicum, Uniwersytet Jagielloński, ul. Prądnicka 80, 31-202 Kraków, e-mail: barbara_malecka@o2.pl 
Trusz-Gluza (Katowice) i Anna Maria Wnuk-Wojnar (Katowice). W sesji wystąpiła przedstawicielka EPIC-Alliance - Doktor Karin Nentwich (Bad Neustadt) demonstrując interesujące plany działania organizacji kobiet zajmujących się inwazyjną elektrokardiologią wraz z przekazaniem zaproszenia do współdziałania. Tym samym można uznać, że obecna konferencja jest początkiem formalnej obecności polskich Pań Kardiologów w strukturach EPIC-Alliance.

Sesje na temat programowania i nowości technologicznych wywołały długą i owocną dyskusję, co spowodowało potrzebę jej przedłużenia, tzn. kontynuacji podczas porannej sesji 13 marca. Beata Iwańska (Radom) wskazała potrzebę rejestracji potencjałów przedsionkowych w celu weryfikacji arytmii w kardiowerterach-defibrylatorach (ICD, implantable cardioverter-defibrylator). Otrzymanie rejestracji tych potencjałów w przypadku zastosowaniu jednej elektrody z pływającymi w przedsionku pierścieniami jest interesującą i obiecującą alternatywą dla implantacji dwuelektrodowych systemów ICD. Aleksandra Woźniak (Zabrze) przedstawiła doświadczenia swojego ośrodka (zabrzańskiego) - potentata na polskim rynku w zakresie kontroli urządzeń wszczepialnych poprzez przesyłanie danych na odległość. Taka kontrola stała się sposobem na skuteczne i bezpieczne prowadzenie pacjentów po zabiegach implantacji ICD, zmieniając jednocześnie profil pacjentów wizytujących tradycyjne przyszpitalne poradnie sprzętowe. W konsekwencji częściej pojawiają się w nich pacjenci wymagający decyzji terapeutycznych, a nie przychodzący w celu dokonania rutynowej, okresowej kontroli urządzenia. Elżbieta Zinka (Koszalin) zreferowała aktualne możliwości badania za pomocą rezonansu magnetycznego u osób po implantacji urządzeń wszczepialnych. Podczas dyskusji poruszono problem braku przygotowania pracowni rezonansu magnetycznego do monitorowania rytmu, zapisów elektrokardiogramów i innych parametrów życiowych wymaganych u pacjentów ze schorzeniami kardiologicznymi, a szczególnie po implantacjach urządzeń sterujących rytmem serca. Elżbieta Dułak (Gdynia) niezwykle prosto i dydaktycznie omówiła przebieg zabiegu ablacji cieśni z powodu trzepotania przedsionków.

W sesji przypadków klinicznych podzielono się wątpliwościami i własnymi doświadczeniami. Aleksandra Woźniak (Zabrze) przedstawiła przypadek pacjenta z niewydolnością serca i zaburzeniami rytmu, u którego 4-letnie wydłużenie życia zostało okupione wieloma interwencjami diagnostycznymi i leczniczymi, w tym implantacją urządzenia do terapii resynchronizującej, ablacją częstoskurczów komorowych w przebiegu burzy elektrycznej i rewaskularyzacją serca. Barbara Dominik (Nowa Sól) pokazała problemy, z którymi musi się zmierzyć lekarz implantujący elektrody endokawitarne. Hanna Wilk-Manowiec (Siedlce) podzieliła się swoimi doświadczeniami z trudnymi decyzjami o implantacji stymulatorów i konsekwencjami tych decyzji, czyli powikłaniami przewlekłej stymulacji serca. Ewa Makowska (Warszawa) zaprezentowała przypadek pacjenta w zaawansowanym wieku metrykalnym, u którego zastosowano z powodzeniem, szereg inwazyjnych zabiegów elektroterapii.

Ostatnią była sesja pt.: „Blaski i cienie implantacji ICD w prewencji pierwotnej nagłego zgonu sercowego". Maria Miszczak-Knecht (Warszawa) ukazała ten problem w populacji dzieci i młodocianych pacjentów, podkreślając dylematy psychologiczne pojawiające się po adekwatnych i nieadekwatnych wyładowaniach urządzenia. Barbara Małecka (Kraków) przedstawiła największą grupę pacjentów otrzymujących ICD w kardiomiopatiach niedokrwiennej i nieniedokrwiennej, z sukcesem jakim jest udowodniona skuteczność tego leczenia w porównaniu do konwencjonalnej farmakoterapii niewydolności serca. Obecnie należy skupić się na eliminacji powikłań tak wczesnych jak i odległych tej terapii ze szczególnym uwzględnieniem infekcji związanych z układami ICD. W analizie powikłań infekcyjnych podkreśliła potrzebę odróżniania infekcji miejscowej od ogólnej, a w szczególności od odelektrodowego zapalenia wsierdzia (LDIE, lead-dependent infective endocarditis). To odróżnienie jest istotne tak w opracowaniach naukowych jak i w codziennej praktyce klinicznej, przekładając się na czas antybiotykoterapii po zabiegach usunięcia elektrod jak też na decyzje o ponownej implantacji. Obecnie w Polsce obserwuje się nadrozpoznawalność LDIE, co jest równie groźnym zjawiskiem jak opóźnienie właściwego rozpoznania. Elżbieta Katarzyna Biernacka (Warszawa) omówiła zastosowanie ICD w kardiomiopatiach przerostowej i arytmogennej prawej komory komentując wprowadzony licznik ryzyka nagłego zgonu w kardiomiopatii przerostowej. Katarzyna Mizia-Stec (Katowice) wyczerpująco przedstawiła problem burzy elektrycznej z jej multidyscyplinarnym leczeniem aż do ablacji substratu arytmii komorowej. Patrycja Pruszkowska (Zabrze) na podstawie swoich doświadczeń i danych z piśmiennictwa pokazała ablację arytmii komorowej jako pierwszą i jedyną terapię burzy elektrycznej.

Udane i owocne spotkanie powinno być kontynuowane w następnych latach wraz z rozwinięciem problemów kwalifikacji do przewlekłej stymulacji serca i kardiowersji/ /defibrylacji, ze szczególnym uwzględnieniem trudnych decyzji leczniczych i powikłań terapii. Spotkanie kobiet elektrokardiologów ukazało ich zaangażowanie a także należyty krytycyzm tak wobec własnego działania leczniczego jak też w stosunku do opublikowanych wytycznych i istniejących ograniczeń administracyjnych. Sukcesem będzie, jeżeli propozycja współpracy z EPIC-Alliance przełoży się na aktywną wymianę doświadczeń oraz - przytaczając za agendą konferencji - ułatwi rozwój karier kobiet w tej trudnej dziedzinie medycyny. Szczególne podziękowania należą się organizatorkom spotkania, które potrafiły zachęcić do spotkania niezbyt liczną grupę Pań Kardiologów, mających swoje doświadczenia i nade wszystko sukcesy na polu diagnostyki oraz leczenia arytmii. Firmie BIOTRONIK natomiast należy pogratulować pomysłu. Dziękując za zabezpieczenie logistyczne należy mieć nadzieję, że to "feministyczne" polskie spotkanie będzie kontynuowane w kolejnych latach, już z logo EPIC-Alliance. 